Article

\title{
Synthesis, Anti-proliferative Activity, and Molecular Docking Study of New Series of 1,3-5-Triazine Schiff Base Derivatives
}

\author{
Hessa H. Al Rasheed ${ }^{1, *}$, Azizah M. Malebari ${ }^{2}$, Kholood A. Dahlous ${ }^{1}$, Darren Fayne ${ }^{3}$ \\ and Ayman El-Faham 1,4,*iD \\ 1 Department of Chemistry, College of Science, King Saud University P.O. Box 2455, Riyadh 11451, \\ Saudi Arabia; kdahloos@ksu.edu.sa \\ 2 Department of Pharmaceutical Chemistry, College of Pharmacy, King Abdulaziz University, \\ Jeddah 21589, Saudi Arabia; amelibary@kau.edu.sa \\ 3 Molecular Design Group, School of Biochemistry and Immunology, Trinity Biomedical Sciences Institute, \\ Trinity College Dublin, Dublin 2, Ireland; fayned@tcd.ie \\ 4 Chemistry Department, Faculty of Science, Alexandria University, P.O. Box 426, Ibrahimia, \\ Alexandria 12321, Egypt \\ * Correspondence: halbahli@ksu.edu.sa (H.H.A.R.); \\ aelfaham@ksu.edu.sa or aymanel_faham@hotmail.com (A.E.-F.); Tel.: +00-9661-1467-3195 (A.E-F.)
}

Academic Editors: Jóhannes Reynisson FRSC and Diego Muñoz-Torrero

Received: 12 August 2020; Accepted: 4 September 2020; Published: 5 September 2020

\begin{abstract}
Based on the use of s-triazine as a scaffold, we report here a new series of s-triazine Schiff base derivatives and their anti-proliferative activity against two cancer cell lines: human breast carcinoma (MCF-7), and colon cancer (HCT-116) compared with tamoxifen as a reference compound. Several derivatives exhibited growth inhibition activity in the sub-micromolar range. The results reveal that the s-triazine Schiff base derivatives showed varied activities and that the substituents on the $s$-triazine core have a great effect on the anti-proliferative activity. Compounds with a piperidino and benzylamino substituent on the s-triazine moiety $\mathbf{4 b}$ and $\mathbf{4 c}$ were most effective in both cell lines compared to the reference compound used. In addition, compound $\mathbf{4 b}$ has a para chlorine atom on the benzylidine residue, demonstrating the most potent activity with $\mathrm{IC}_{50}$ values of 3.29 and $3.64 \mu \mathrm{M}$ in MCF-7 and HCT-116, respectively. These results indicate that in general, the nature of the substituents on the triazine core and the type of substituent on the benzilyldene ring significantly influenced the anti-proliferative activity. The results obtained from the anti-proliferative activity and the molecular docking study indicate that s-triazine-hydrazone derivatives may be an excellent scaffold for the development of new anti-cancer agents.
\end{abstract}

Keywords: s-triazine; schiff base; MCF-7; HCT-116; apoptosis; molecular docking

\section{Introduction}

After cardiovascular diseases, cancer is the second most common cause of death globally, and its occurrence is predicted to increase dramatically in the near future. The high occurrence and death ratio of cancer is because there are more than 270 types of cancer that have a great tendency to resist chemotherapeutics and few cancers are diagnosed in their early stages. For all these reasons, research is essential for cancer treatments providing more effective and less toxic agents [1-4].

1,3,5-Triazine (s-triazine) is one of the most fascinating chemical cores in medicinal chemistry applications due to the broad range of biological activities such as anti-microbial [5], antifungal [6], antimalarial [7], carbonic anhydrase inhibitors [8-12] and anti-cancer agents [13-17]. 
On the other hand, Schiff bases are compounds formed by a condensation reaction between hydrazine or primary amines and carbonyl compounds to form azomethine type compounds $(\mathrm{CH}=\mathrm{NH}-)$ and are considered to be important derivatives with biological, medicinal, clinical, pharmacological and analytical applications [18-21]. In addition, they are popular ligand precursors due to their versatility and ease of preparation.

Schiff bases containing s-triazine core showed a wide diversity of biological activities such as anti-cancer, antimycobacterial, antibacterial, antidepressant, analgesic properties and enzyme inhibitors [22-26]. Moreover, 1,3,5-triazine derivatives have been shown to bind to and modulate estrogen receptor alpha $(E R \alpha)$ and estrogen receptor beta $(E R \beta)[27,28]$. Very recently, Lu et al., reported the synthesis of 1,3,5-triazine-based derivatives as selective estrogen receptor degraders (SERDs). Most of these compounds showed anti-proliferative activities in MCF-7 cells [29].

In continuation of our studies on s-triazine-hydrazone derivatives and their anti-cancer activity against breast cancer cells (MCF-7) and colon cancer (HCT-116) [30-32], herein we report a new series of Schiff bases encompassing $s$-triazine core and benzylidene moieties with different substituents (Figure 1). The compounds' anti-proliferative activities against breast cancer MCF-7 and colon carcinoma HCT-116 cell lines were evaluated. In addition, molecular docking of the compound series within the hypothesized biological target $(\mathrm{ER} \alpha)$ will be discussed.

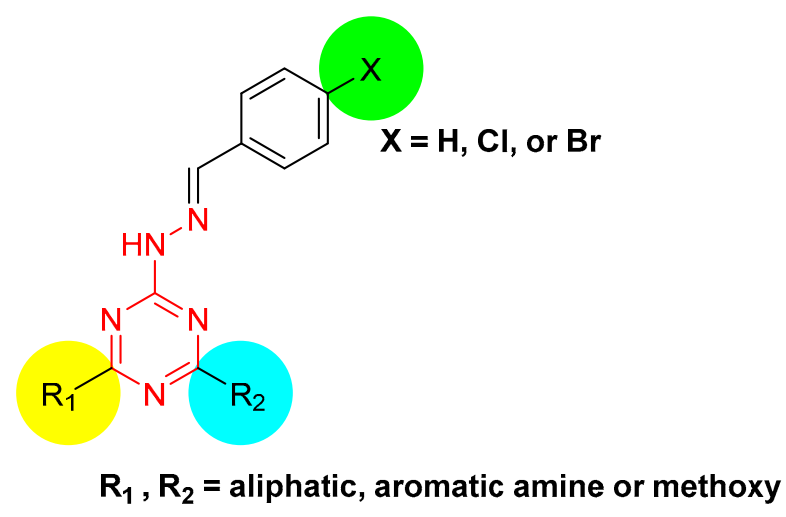

Figure 1. Structure of the novel synthesized s-triazine compounds.

\section{Results and Discussion}

\subsection{Chemistry}

The target compounds 4a-r were synthesized as illustrated in Scheme 1 following the reported methods [31-34]. The hydrazine derivatives 2 were reacted with $p$-substituted benzaldehyde derivatives 3a-c in the presence of acetic acid $(\mathrm{AcOH})$ and using ethanol as a solvent to give the target compounds 4a-r (Scheme 1). The structures of 4a-r were established by elemental analysis, Fourier-transform infrared spectroscopy (FTIR), ${ }^{1} \mathrm{H}-\mathrm{NMR}$, and ${ }^{13} \mathrm{C}-\mathrm{NMR}$ spectra (Supplementary information, Figures S1-S18). 


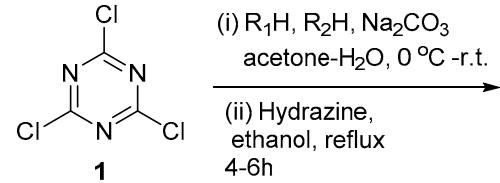

$\begin{array}{lll}\text { Cpd } & \mathbf{X} & \mathbf{R} \mathbf{1} \\ \mathbf{4 a} & \mathrm{H} & \text { piperidine } \\ \mathbf{4 b} & \mathrm{Cl} & \text { piperidine } \\ \mathbf{4 c} & \mathrm{Br} & \text { piperidine } \\ \mathbf{4 d} & \mathrm{H} & \text { piperidine } \\ \mathbf{4 e} & \mathrm{Cl} & \text { piperidine } \\ \mathbf{4 f} & \mathrm{Br} & \text { piperidine } \\ \mathbf{4 g} & \mathrm{H} & \text { morpholine } \\ \mathbf{4 h} & \mathrm{Cl} & \text { morpholine } \\ \mathbf{4 i} & \mathrm{Br} & \text { morpholine }\end{array}$

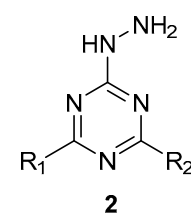

$$
\mathbf{R}_{\mathbf{2}}
$$

benzylamine benzylamine benzylamine methoxy methoxy methoxy benzylamine benzylamine benzylamine

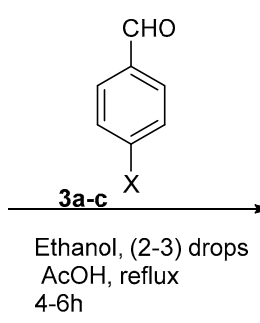

$\begin{array}{ll}\text { Cpd } & \mathbf{X} \\ \mathbf{4 j} & \mathrm{H} \\ \mathbf{4 k} & \mathrm{Cl} \\ \mathbf{4 l} & \mathrm{Br} \\ \mathbf{4 m} & \mathrm{H} \\ \mathbf{4 n} & \mathrm{Cl} \\ \mathbf{4 0} & \mathrm{Br} \\ \mathbf{4 p} & \mathrm{H} \\ \mathbf{4 q} & \mathrm{Cl} \\ \mathbf{4 r} & \mathrm{Br}\end{array}$<smiles>[X]c1ccc(/C=N/Nc2nc([R])nc([R])n2)cc1</smiles>

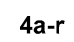

$R_{1}$

morpholine morpholine morpholine morpholine morpholine morpholine phenylamine phenylamine

\begin{tabular}{l}
\multicolumn{1}{c}{$\mathbf{R}_{\mathbf{2}}$} \\
methoxy \\
methoxy \\
methoxy \\
phenylamine \\
phenylamine \\
phenylamine \\
methoxy \\
methoxy \\
methoxy
\end{tabular}

Scheme 1. Synthetic route for preparation of $s$-triazine Schiff base derivatives.

\subsection{Biology}

\subsubsection{Anti-Proliferative Activity and Induced Apoptosis}

$s$-Triazine-hydrazone derivatives 4a-r were screened for their anti-proliferative activity against two representative human cancer cell lines; breast cancer MCF-7 and colon cancer HCT-116 and compared with tamoxifen [35] as a reference compound using (3-(4,5-dimethylthiazol-2-yl)-2,5-diphenyltetrazolium bromide (MTT) assay. Based on the data illustrated in Table 1 (Supporting information, Method S1), the s-triazine-hydrazone derivatives displayed varied anti-proliferative activity, with better efficacy on MCF-7 than HCT-116 cells. Generally, the nature of the substituents on the triazine ring significantly influenced the biological activity. s-Triazine-hydrazone derivatives $4 \mathrm{~m}, 4 \mathrm{n}$, and $4 \mathbf{o}$ (containing morpholine and phenylamine on the triazine core) showed potent anti-proliferative in MCF-7 and HCT-116 cells with $\mathrm{IC}_{50}$ values of 7.93, 6.10, and $6.58 \mu \mathrm{M}$ and 5.10, 4.54, $10.41 \mu \mathrm{M}$, respectively. Interestingly, replacement of the morpholine ring in compounds $\mathbf{4 m - \mathbf { m }}$ with a methoxy group to furnished compounds $4 \mathbf{p}-\mathbf{r}$ maintained good to moderate anti-proliferative in MCF-7 with $\mathrm{IC}_{50}$ values in the range of 3.98-10.44 $\mu \mathrm{M}$. To examine the significance of the phenylamino substituent on the triazine ring, a related series of benzylamino substituent analogs including compounds $\mathbf{4 a - c}$ (containing piperidine on the triazine core) and compounds $4 \mathbf{g}-\mathbf{i}$ (containing morpholine on the triazine core) were next evaluated. Compounds $4 \mathbf{b}$ and $4 \mathbf{c}$, with a piperidine ring, showed more potent anti-proliferative activity with, $\mathrm{IC}_{50}$ values of 3.29 and $4.63 \mu \mathrm{M}$ in MCF-7 cell lines and 3.64 and $5.60 \mu \mathrm{M}$ in HCT-116 cell lines, respectively compared to their corresponding analogs with a morpholine ring in compounds $4 \mathrm{~g}-\mathbf{i}\left(\mathrm{IC}_{50}\right.$ values in range of $16.44-24.46 \mu \mathrm{M}$ and $8.19-14.01 \mu \mathrm{M}$ in MCF-7 and HCT-116, respectively) and compared with tamoxifen as a reference compound ( $\mathrm{IC}_{50}$ values of 5.12 and $26.41 \mu \mathrm{M}$ in MCF-7 and HCT-116 cells, respectively) as shown in Table 1 . These results could reflect the importance of a piperidine substituent on the triazine ring as a less polar group for optimum activity in cancer cells. These results are consistent with our previously reported results, where the piperidine derivatives showed better activity compared to their corresponding morpholine analogs $[33,34,36]$.

Conversely, replacement of the phenylamino substituent on the triazine moiety in compounds $\mathbf{4 m}-\mathbf{o}$ with a small group as a methoxy group (compounds $\mathbf{4 d} \mathbf{d} \mathbf{f}$ and $\mathbf{4 j}-\mathbf{l}$ ) significantly affected the anti-proliferative activity with a 2.5-5.5 and 3.7-12.5-fold loss in the potency on MCF-7 and HCT-116 cells, respectively. For example, replacement of phenylamino in morpholine substituted triazine derivative $4 \mathbf{n}$ with a methoxy group in $4 \mathbf{j}$ resulted in a marked decrease in the activity in both cell lines: $\mathrm{IC}_{50}$ values for $4 \mathrm{n}$ were 6.10 and $4.54 \mu \mathrm{M}$ vs. $\mathrm{IC}_{50}$ values for $4 \mathbf{k}$ were 14.08 and $42.34 \mu \mathrm{M}$ in MCF-7 and HCT-116 cells, respectively. 
However, it was observed that methoxy s-triazine-hydrazone compounds $4 \mathbf{p}-\mathbf{r}$ with phenyl amine moiety, exhibited better anti-proliferative activity compared to their analogs $4 \mathbf{d}-\mathbf{f}$ (piperidine derivatives) and derivatives $\mathbf{4 j - 1}$ (morpholine derivatives) as shown in Table 1. For example, $\mathbf{4} \mathbf{p}$ vs. $\mathbf{4} \mathbf{d}$ and $\mathbf{4 j}$, exhibited significant activity against both tested cell lines. These results agreed with the reported data, where aromatic amines can help to enhance biological activity [37,38].

Table 1. Anti-proliferative effects of $\mathbf{4 a -} \mathbf{a}$ series compounds in MCF-7 and HCT-116 cells.

\begin{tabular}{ccc}
\hline Compound no. & $\begin{array}{c}\mathbf{I C}_{\mathbf{5 0}}(\boldsymbol{\mu M})^{\mathbf{a}} \\
\mathbf{M C F - 7}\end{array}$ & $\begin{array}{c}\mathbf{I C}_{\mathbf{5 0}}(\boldsymbol{\mu M})^{\mathbf{a}} \\
\text { HCT-116 }\end{array}$ \\
\hline 4a & $11.35 \pm 1.81$ & $12.45 \pm 1.16$ \\
$4 \mathrm{~b}$ & $3.29 \pm 0.83$ & $3.64 \pm 1.58$ \\
$4 \mathrm{c}$ & $4.63 \pm 0.40$ & $5.60 \pm 1.97$ \\
$4 \mathrm{~d}$ & $28.62 \pm 2.80$ & $>50$ \\
$4 \mathrm{e}$ & $33.90 \pm 0.94$ & $>50$ \\
$4 \mathrm{f}$ & $18.49 \pm 1.03$ & $>50$ \\
$4 \mathrm{~g}$ & $24.46 \pm 1.83$ & $14.01 \pm 1.61$ \\
$4 \mathrm{~h}$ & $16.44 \pm 1.13$ & $8.19 \pm 0.22$ \\
$4 \mathrm{i}$ & $22.20 \pm 2.59$ & $12.22 \pm 0.34$ \\
$4 \mathrm{j}$ & $18.59 \pm 1.62$ & $24.10 \pm 3.94$ \\
$4 \mathrm{k}$ & $14.08 \pm 0.06$ & $42.34 \pm 4.74$ \\
$4 \mathrm{l}$ & $26.91 \pm 1.20$ & $37.29 \pm 0.34$ \\
$4 \mathrm{~m}$ & $7.93 \pm 0.77$ & $5.10 \pm 1.01$ \\
$4 \mathrm{n}$ & $6.10 \pm 0.42$ & $4.54 \pm 0.41$ \\
$4 \mathrm{o}$ & $6.58 \pm 0.65$ & $10.71 \pm 2.91$ \\
$4 \mathrm{p}$ & $3.98 \pm 0.22$ & $8.45 \pm 0.24$ \\
$4 \mathrm{q}$ & $9.37 \pm 1.74$ & $6.26 \pm 0.49$ \\
$4 \mathrm{r}$ & $10.44 \pm 0.43$ & $7.57 \pm 1.34$ \\
Tamoxifen ${ }^{\mathrm{b}}$ & $5.12 \pm 0.36$ & $26.41 \pm 4.11$ \\
\hline
\end{tabular}

${ }^{\mathrm{a}} \mathrm{IC}_{50}$ values are half maximal inhibitory concentrations required to block the growth stimulation of cells. Values represent the mean for three experiments performed in triplicate; ${ }^{\mathrm{b}} \mathrm{The} \mathrm{IC}_{50}$ value obtained for CA- 4 $(5.12 \mu \mathrm{M}$ for MCF-7 and $26.41 \mu \mathrm{M}$ for HCT-116) are in good agreement with reported values [39,40].

With the exception of compounds $\mathbf{4} \mathbf{d}-\mathbf{f}$ and $\mathbf{4 j} \mathbf{j} \mathbf{l}$, the introduction of electron-withdrawing groups such as chloro and bromo substituent on the benzylidene ring with different substituted s-triazine motifs demonstrated good anti-cancer activities against both cell lines in the low micromolar range compared to its corresponding unsubstituted analogs. Derivatives with piperidino and benzylamino substituent on the triazine moiety $\mathbf{4 b}$ (chloro substituent) and $4 \mathbf{c}$ (bromo substituent) showed the most potent activities in this series in both cell lines as shown in Table 1 and Figures 2 and 3.

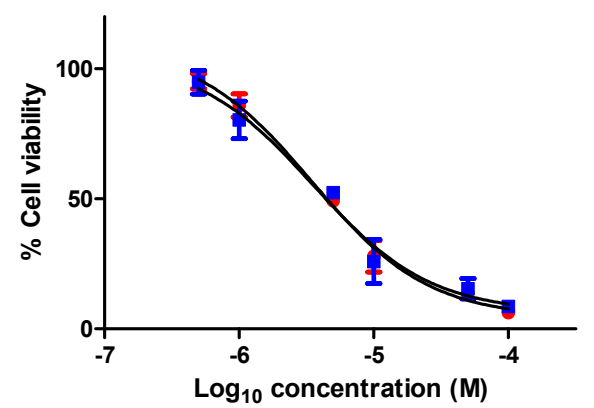

- $\mathrm{MCF}-7\left(\mathrm{IC}_{50}=3.29 \mu \mathrm{M}\right)$

- $\mathrm{HCT}-116\left(\mathrm{IC}_{50}=3.64 \mu \mathrm{M}\right)$

Figure 2. Anti-proliferative effect of $\mathbf{4 b}$ in MCF-7 and HCT-116 cells. Cells were grown in 96-well plates and treated with $4 \mathrm{~b}$ at $0.1 \mu \mathrm{M}$ to $100 \mu \mathrm{M} 0.05-100 \mu \mathrm{M}$ for $72 \mathrm{~h}$. Cell viability was expressed as a percentage of vehicle control [ethanol $0.1 \%(\mathrm{v} / \mathrm{v})$ ] treated cells. The values represent the mean \pm S.E.M. for three independent experiments performed in triplicate. 


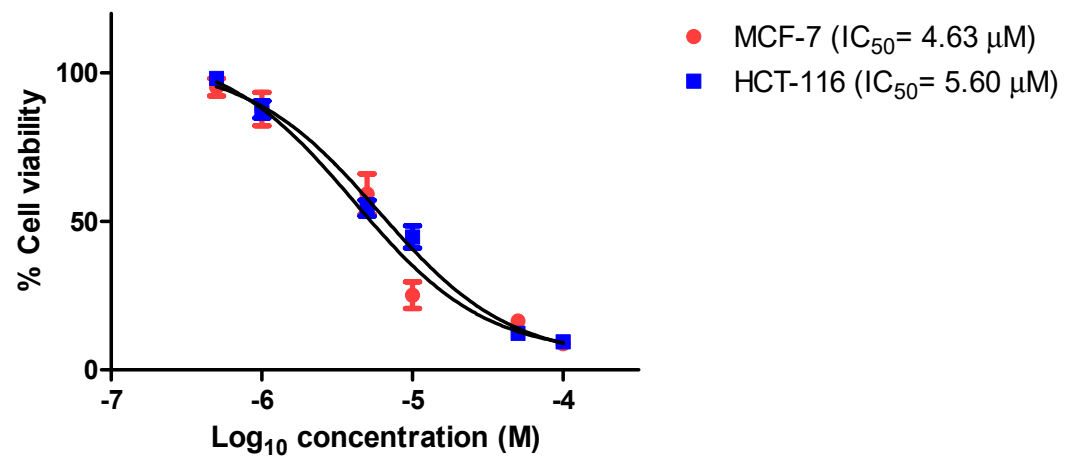

Figure 3. Anti-proliferative effect of 4c in MCF-7 and HCT-116 cells. Cells were grown in 96-well plates and treated with $4 \mathrm{c}$ at $0.1 \mu \mathrm{M}$ to $100 \mu \mathrm{M}$ for $72 \mathrm{~h}$. Cell viability was expressed as a percentage of vehicle control [ethanol $0.1 \%(\mathrm{v} / \mathrm{v})$ ] treated cells. The values represent the mean \pm S.E.M. for three independent experiments performed in triplicate.

Finally, s-triazine-hydrazone derivatives that encompass benzylamino and piperidino rings on the $s$-triazine core can be envisaged as interesting novel molecules with promising anti-proliferative activities in MCF-7 and HCT-116 cell lines.

Based on the obtained results, we examined apoptosis in MCF-7 cells after treatment with the most active compound $\mathbf{4 b}$. The percentage of early and late apoptotic cells was determined by double staining with Annexin V and PI via flow cytometry. Positioning of quadrants on dot plots was designated, and living cells (Annexin V-/PI-), early apoptotic cells (Annexin V+/PI-), late apoptotic cells (Annexin $\mathrm{V}+/ \mathrm{PI}+$ ) and necrotic cells (Annexin $\mathrm{V}-/ \mathrm{PI}+$ ) were identified. The data shown in Figure 4 prove that the MCF-7 cells were incubated with $4 \mathrm{~b}$ at a concentration of $6 \mu \mathrm{M}$ for $24 \mathrm{~h}$ decreased the population of viable cells and increasing the percentage of apoptotic cells. The percentage of early and late apoptotic cells together of $\mathbf{4 b}$ increased after $24 \mathrm{~h}$ to $21.81 \%$ and $6.93 \%$, respectively at $6 \mu \mathrm{M}$ when compared to the control cells $(2.23 \%)$ as shown in Figure 4.
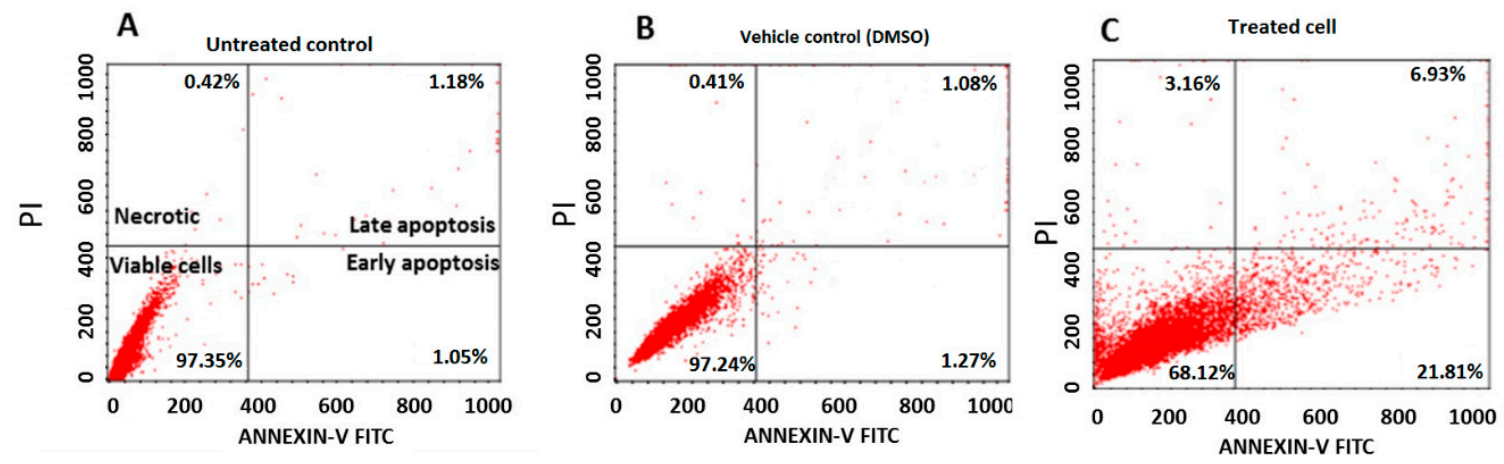

Figure 4. Flow cytometric analysis (Annexin V-FTIC/PI assay) of MCF-7 cells exposed for $24 \mathrm{~h}$ to $4 \mathrm{~b}$ (C) (approximately $2 x \mathrm{IC}_{50}$ value), respectively. $\mathbf{A}=$ untreated control, and $\mathbf{B}$ vehicle control (DMSO). The represented dot plots showing percentage of viable, early apoptotic, late apoptotic, and necrotic cells.

These results show the ability of $4 \mathrm{~b}$ to induce apoptosis in cancer cells and may deliver an excellent scaffold for the development of anti-cancer drug candidates. 


\subsubsection{Molecular Docking Study}

Estrogen actions are mainly mediated through two nuclear estrogen receptor (ER) subtypes namely $\mathrm{ER} \alpha$ and ER $\beta$ [41,42]. In Western blot analyses, the antibody against ER $\alpha$ detected a single sharp band related to the expected molecular weight of $72 \mathrm{kD}$ in all MCF-7 subclones. In agreement with Western blot analyses, a high expression of the ER $\alpha$ mRNA was detected in MCF-7 [43]. Accordingly, an in-depth binding pose analysis on all compounds with ER $\alpha$ was performed.

The top docked pose of each compound was analyzed and mapping to the X-ray structure ligands binding poses was considered (Supporting information, Method S2). The triazine derivatives 4a-r were scored following docking, in order of preference. This ranking broadly maps to the cellular efficacy biological data, as the $4 \mathbf{a}-\mathbf{c}$ series are the most potent compounds while the $4 \mathbf{j}-\mathbf{l}$ and $4 \mathbf{d}-\mathbf{f}$ series are the least potent and $\mathbf{4 p - q}$ have moderate potency.

Analysis of the predicted binding poses assisted to illustrate the potency trends. The most potent compounds ( $4 \mathbf{b}$ and $4 \mathbf{c}$ ) had near identical scores ( -7.8387 and -7.8355 respectively). As shown in Figure $5 a$ and $b$, the halogenated benzylidene ring mapped to the tertiary amine group of 4-hydroxytamoxifen (4-OHT), the triazine ring mapped to the 4-OHT A ring, the benzyl ring mapped to the 4-OHT B ring and the piperidine ring mapped to the 4-OHT C ring. Binding was primarily driven by hydrophobic and van der Waals interactions due to the benzyl and piperidine rings occupying apolar sub-pockets in the ER $\alpha$ binding site. The benzyl group was in a sub-pocket comprising of Leu349, Ala350, Leu391, and Phe404. The group did not make interactions with the polar Glu353 and Arg394 amino acids deeper in the sub-pocket, which will be a future route for compound optimization. The piperidine ring occupied a sub-pocket encompassing Val418, Ile424, Leu525, and Leu346. The amine of the benzylidene chain can make a hydrogen bond donor interaction with a co-crystallized water molecule but did not make a hydrogen bond with the important Asp351 residue. The halogens are $2.91 \AA$ from the backbone nitrogen atom of Cys530 so may make an attractive electrostatic interaction.

Conversely, the worst ranked docked series, for example, 41 (Figure $5 \mathrm{c}$ ) was unable to recapitulate the favorable interactions formed by the benzyl group of the $4 \mathbf{a}-\mathbf{c}$ series. The more polar morpholine ring in $\mathbf{4 g}-\mathbf{i}$ series is also not preferred to the piperidine ring of the $\mathbf{4 a - c}$ series as it was in a hydrophobic sub-pocket. Due to the smaller substituent sizes, the docked compound was located lower in the binding site so the triazine group is not overlaid on the 4-OHT A ring. Similar binding poses were found for the piperidine and methoxy on the triazine series $4 \mathbf{d}-\mathbf{f}$ (i.e., $4 \mathbf{f}$, Figure $5 \mathrm{~d}$ ), in that the methoxy group occupies one of the hydrophobic sub-pockets and the compound is located lower in the binding site.

In summary, the results obtained from molecular docking are consistent with the results obtained from the anti-proliferative activity screening, where the most active series are compounds with piperidine and benzylamine on the triazine core. 


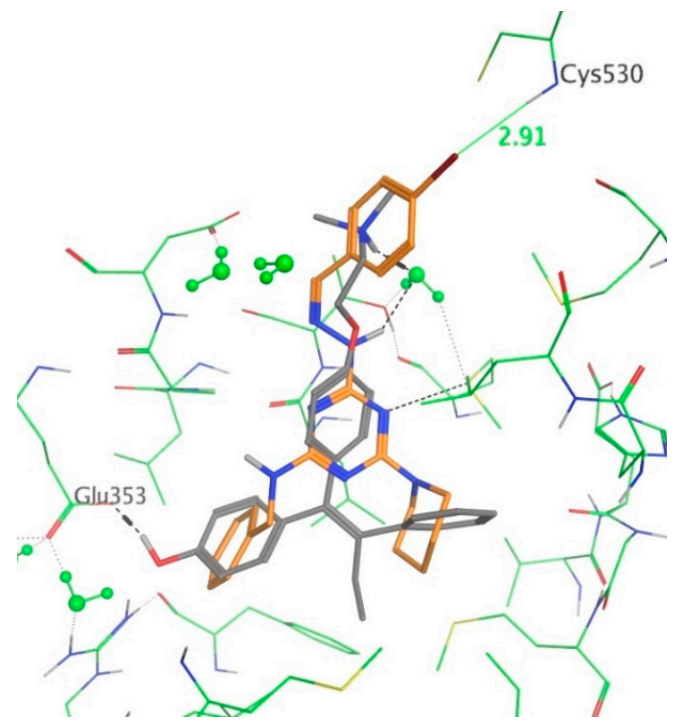

a
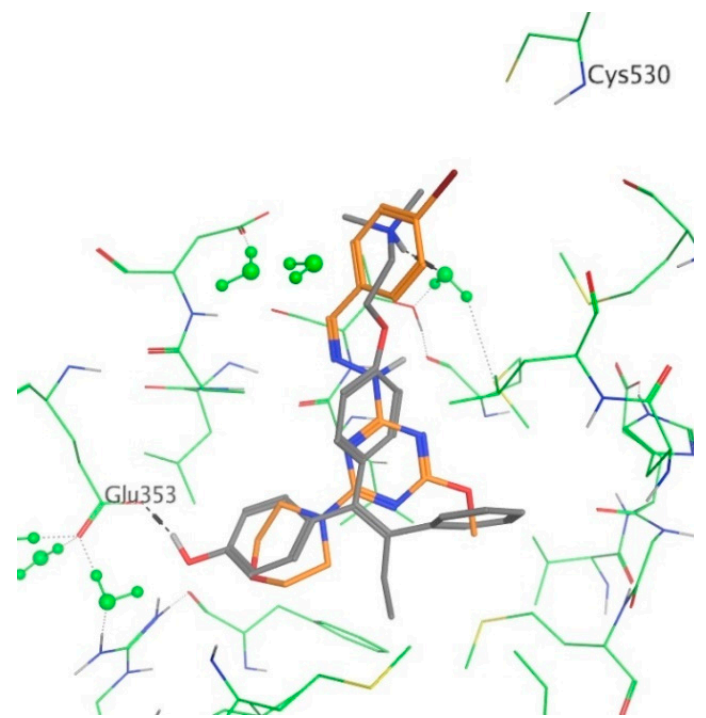

C

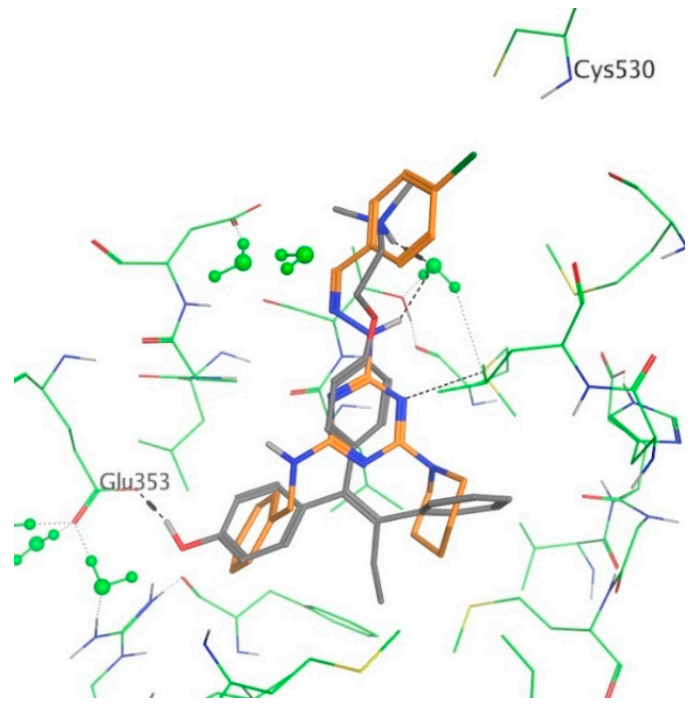

b
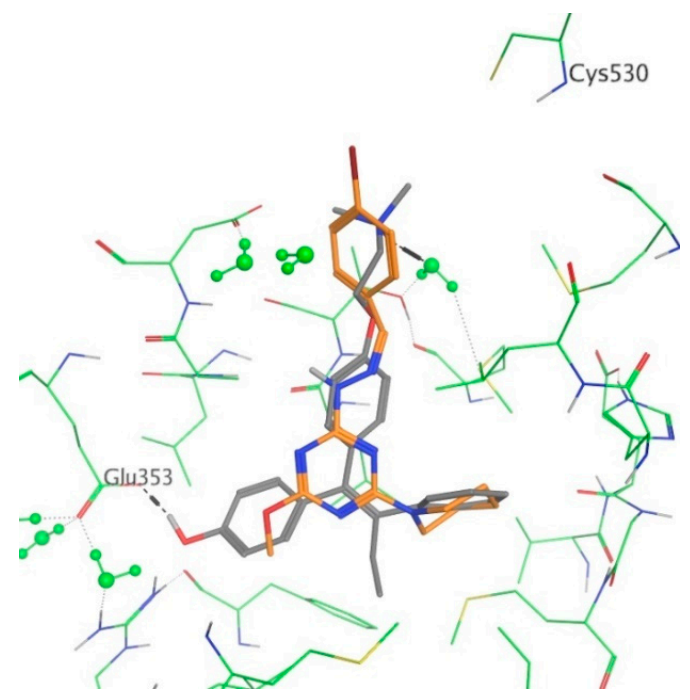

d

Figure 5. Best ranked docked poses of (a) 4c, (b) 4 b, (c) 41 and (d) $4 \mathrm{f}$ in ER $\alpha$ overlaid on the 4-OHT X-ray structure 3ERT generated with the Molecular Operating Environment (MOE) 2019 software. Carbon atoms are illustrated in grey for 4-OHT, orange for the docked compounds and light green for the protein (oxygen atoms—red; nitrogen—dark blue; sulfur-yellow; bromine-dark red and chlorine-dark green). ER $\alpha$ and associated water molecules are in light green.

\section{Materials and Methods}

All reagents and solvents purchased from commercial suppliers and used without further purification. ${ }^{1} \mathrm{H}-\mathrm{NMR}$ and ${ }^{13} \mathrm{C}-\mathrm{NMR}$ spectra were recorded on a JEOL $400 \mathrm{MHz}$ spectrometer (JEOL, Ltd., Tokyo, Japan), and chemical shift $(\delta)$ values were expressed in ppm. Elemental analyses performed on Perkin-Elmer 2400 elemental analyzer (PerkinElmer, Inc.940 Winter Street, Waltham, MA, USA). Melting points were recorded on a Mel-Temp apparatus Sigma-Aldrich Chemie GmbH, 82024 Taufkirchen, Germany) in an open capillary and are uncorrected. Fourier transform infrared spectroscopy (FTIR) recorded on Shimadzu 8201 PC FTIR spectrophotometer (Shimadzu, Ltd., Kyoto, Japan). The reaction was follow-up and checks of the purity using thin layer liquid chromatograph (TLC) on silica gel-protected aluminum sheets (Type 60 GF254, Merck). 


\subsection{General Method for the Synthesis of 1,3,5-triazine Schiff Base Derivatives}

2-Hydrazino-4,6-disubstituted-1,3,5-triazine derivatives 2 were synthesized first following the reported methods $[26,32-34,36]$ and used directly without further purification into the next step.

Hydrazine derivatives 2 were reacted with aldehyde derivatives $3 a-c(10 \mathrm{mmol})$ in ethanol $(30 \mathrm{~mL})$ in the presence of 2-3 drops of acetic acid at room temperature. The reaction mixture was refluxed for 4-6 h, and the progress of the reaction was follow by TLC using ethyl acetate-hexane 2:1. After completion of the reaction, the mixture left to cool down to room temperature and the solid product was collected by filtration, washed with cooled ethanol, and then dried at room temperature.

N-benzyl-4-(2-benzylidenehydrazinyl)-6-(piperidin-1-yl)-1,3,5-triazin-2-amine (4a). the product was obtained as a white solid in yield 83\%; $\mathrm{mp} 148-150{ }^{\circ} \mathrm{C}$; IR $\left(\mathrm{KBr}, \mathrm{cm}^{-1}\right)$ : $3241(\mathrm{NH}), 1662(\mathrm{C}=\mathrm{N}), 1590$, $1545(\mathrm{C}=\mathrm{C}) ;{ }^{1} \mathrm{H}-\mathrm{NMR}\left(400 \mathrm{MHz}, \mathrm{DMSO}-d_{6}\right): \delta=1.40$ (brs, $\left.4 \mathrm{H}, 2 \mathrm{CH}_{2}\right), 1.55$ (brs, 2H, $\left.\mathrm{CH}_{2}\right), 3.65(\mathrm{brs}, 4 \mathrm{H}$, $\left.2 \mathrm{NCH}_{2}-\right)$, 4.39-4.45 (m, 2H, $\left.\mathrm{CH}_{2}-\mathrm{NH}\right), 7.16-7.36(\mathrm{~m}, 8 \mathrm{H}, \mathrm{Ar}), 7.57$ (s, 2H, Ar), 8.03 (s, 1H, CH), 10.57 (brs, 1H, NH) ), 10.64 (brs, 1H, NH) ppm; ${ }^{13}$ C-NMR $\left(100 \mathrm{MHz}, \mathrm{DMSO}-d_{6}\right): \delta=24.9,25.9,43.4$, $56.6,126.7,126.9,127.9,128.6,129.2,129.4,135.7,141.3,141.9,164.8,166.5$ ppm. Anal. Calcd for $\mathrm{C}_{22} \mathrm{H}_{25} \mathrm{~N}_{7}$ (387.48): C, 68.19; H, 6.50; N, 25.30. Found C, 68.32; H, 6.66; N, 25.50.

N-benzyl-4-(2-(4-chlorobenzylidene)hydrazinyl)-6-(piperidin-1-yl)-1,3,5-triazin-2-amine (4b). the product was obtained as a white solid in yield 88\%; mp 200-202 ${ }^{\circ} \mathrm{C}$; IR $\left(\mathrm{KBr}, \mathrm{cm}^{-1}\right): 3376(\mathrm{NH}), 1592(\mathrm{C}=\mathrm{N})$, 1516,1442 (C=C); ${ }^{1} \mathrm{H}-\mathrm{NMR}\left(400 \mathrm{MHz}, \mathrm{DMSO}-d_{6}\right): \delta=1.40\left(\mathrm{brs}, 4 \mathrm{H}, 2 \mathrm{CH}_{2}\right), 1.55\left(\mathrm{brs}, 2 \mathrm{H}, \mathrm{CH}_{2}\right)$, 3.64 (brs, 4H, $\left.2 \mathrm{NCH}_{2}-\right)$, 4.38-4.45 (m, 2H, $\left.\mathrm{CH}_{2}-\mathrm{NH}\right), 7.16(\mathrm{t}, 1 \mathrm{H}, J=7.0 \mathrm{~Hz}, \mathrm{Ar}), 7.23-7.29(\mathrm{~m}, 4 \mathrm{H}, \mathrm{Ar})$, $7.42(\mathrm{~d}, 2 \mathrm{H}, J=8.5 \mathrm{~Hz}, \mathrm{Ar}), 7.58(\mathrm{~d}, 2 \mathrm{H}, J=8.0 \mathrm{~Hz}, \mathrm{Ar}), 8.01(\mathrm{~s}, 1 \mathrm{H}, \mathrm{CH}), 10.66$ (brs, 1H, NH), $10.71(\mathrm{~s}, 1 \mathrm{H}, \mathrm{NH}) \mathrm{ppm} ;{ }^{13} \mathrm{C}-\mathrm{NMR}\left(100 \mathrm{MHz}, \mathrm{DMSO}-d_{6}\right): \delta=24.9,25.9,43.5,56.6,126.9,127.9,128.4$, 128.6, 129.3, 133.7, 134.7, 140.5, 141.2, 164.6, 166.4 ppm. Anal. Calc. for $\mathrm{C}_{22} \mathrm{H}_{24} \mathrm{ClN}_{7}$ (421.93): C, 62.63; H, 5.73; N, 23.24. Found C, 62.54; H, 5.68; N, 23.45.

N-benzyl-4-(2-(4-bromobenzylidene)hydrazinyl)-6-(piperidin-1-yl)-1,3,5-triazin-2-amine (4c). the product was obtained as a white solid in yield $84 \%$; mp $195-197^{\circ} \mathrm{C}$; IR $\left(\mathrm{KBr}, \mathrm{cm}^{-1}\right): 3351(\mathrm{NH}), 1656(\mathrm{C}=\mathrm{N})$, $1548,1514(\mathrm{C}=\mathrm{C}) ;{ }^{1} \mathrm{H}-\mathrm{NMR}\left(400 \mathrm{MHz}, \mathrm{DMSO}-d_{6}\right): \delta=1.40\left(\mathrm{brs}, 4 \mathrm{H}, 2 \mathrm{CH}_{2}\right), 1.55$ (brs, 2H, $\left.\mathrm{CH}_{2}\right)$, 3.65 (brs, 4H, $\left.2 \mathrm{NCH}_{2}-\right)$, 4.40-4.45 (m, 2H, CH $\left.2-\mathrm{NH}\right), 7.14(\mathrm{t}, 1 \mathrm{H}, J=7.0 \mathrm{~Hz}, \mathrm{Ar}), 7.23-7.29$ (m, 4H, Ar), 7.52-7.57 (m, 4H, Ar), 8.00 (s, 1H, CH), 10.72-10.77 (m, 2H, 2NH)) ppm; ${ }^{13} \mathrm{C}-\mathrm{NMR}\left(100 \mathrm{MHz}, \mathrm{DMSO}-d_{6}\right)$ : $\delta=24.9,25.9,43.7,44.1 .9,122.4,127.0,127.9,128.6,132.2,134.9,140.5,140.9,164.8,166.7$ ppm. Anal. Calc. for $\mathrm{C}_{22} \mathrm{H}_{24} \mathrm{BrN}_{7}$ (466.38): C, 56.66; H, 5.19; N, 21.02. Found C, 56.83; H, 5.41; N, 21.27.

2-(2-benzylidenehydrazinyl)-4-methoxy-6-(piperidin-1-yl)-1,3,5-triazine (4d). the product was obtained as a white solid in yield 81\%; mp 221-223 ${ }^{\circ} \mathrm{C}$; IR $\left(\mathrm{KBr}, \mathrm{cm}^{-1}\right)$ : $3219(\mathrm{NH}), 1591(\mathrm{C}=\mathrm{N}), 1542,1513(\mathrm{C}=\mathrm{C})$; ${ }^{1} \mathrm{H}-\mathrm{NMR}\left(400 \mathrm{MHz}, \mathrm{DMSO}-d_{6}\right): \delta=1.47$ (brs, 4H, 2CH$), 1.58$ (brs, 2H, $\left.\mathrm{CH}_{2}\right), 3.70\left(\right.$ brs, $4 \mathrm{H}, 2 \mathrm{NCH}_{2}-$ ), $3.79\left(\mathrm{~s}, 3 \mathrm{H}, \mathrm{OCH}_{3}\right), 7.31-7.39(\mathrm{~m}, 3 \mathrm{H}, \mathrm{Ar}), 7.61(\mathrm{~d}, 2 \mathrm{H}, \mathrm{J}=8.25 \mathrm{~Hz}, \mathrm{Ar}), 8.07$ (s, 1H, CH), 11.08 (s, 1H, NH) ppm; ${ }^{13} \mathrm{C}-\mathrm{NMR}\left(100 \mathrm{MHz}, \mathrm{DMSO}-d_{6}\right): \delta=24.8,25.9,44.3,54.1,127.0,129.3,129.8,135.5$, 143.3, 165.3, 171.5 ppm. Anal. Calc. for $\mathrm{C}_{16} \mathrm{H}_{20} \mathrm{~N}_{6} \mathrm{O}$ (312.37): C, 61.52; $\mathrm{H}, 6.45 ; \mathrm{N}, 26.90$. Found C, $61.71 ; \mathrm{H}, 6.56 ; \mathrm{N}, 27.03$.

2-(2-(4-chlorobenzylidene)hydrazinyl)-4-methoxy-6-(piperidin-1-yl)-1,3,5-triazine (4e). the product was obtained as a white solid in yield 86\%; mp 123-125 ${ }^{\circ} \mathrm{C}$; IR $\left(\mathrm{KBr}, \mathrm{cm}^{-1}\right): 3219(\mathrm{NH}), 1590(\mathrm{C}=\mathrm{N}), 1540$, $1462(\mathrm{C}=\mathrm{C}){ }^{1}{ }^{1} \mathrm{H}-\mathrm{NMR}\left(400 \mathrm{MHz}, \mathrm{DMSO}-d_{6}\right): \delta=1.47$ (brs, 4H, 2CH $\left.\mathrm{CH}_{2}\right), 1.58\left(\mathrm{brs}, 2 \mathrm{H}, \mathrm{CH}_{2}\right), 3.69(\mathrm{brs}, 4 \mathrm{H}$, $\left.2 \mathrm{NCH}_{2}-\right), 3.79\left(\mathrm{~s}, 3 \mathrm{H}, \mathrm{OCH}_{3}\right), 7.43(\mathrm{~d}, 2 \mathrm{H}, J=7.5 \mathrm{~Hz}, \mathrm{Ar}), 7.62(\mathrm{~d}, 2 \mathrm{H}, J=6.5 \mathrm{~Hz}, \mathrm{Ar}), 8.05(\mathrm{~s}, 1 \mathrm{H}, \mathrm{CH})$, 11.15 (s, 1H, NH) ppm; ${ }^{13} \mathrm{C}-\mathrm{NMR}\left(100 \mathrm{MHz}, \mathrm{DMSO}-d_{6}\right): \delta=24.7,25.9,43.7,54.1,128.6,129.4,129.6$, 130.5, 1341, 134.3, 142.0, 165.8, 171.4 ppm. Anal. Calc. for $\mathrm{C}_{16} \mathrm{H}_{19} \mathrm{ClN}_{6} \mathrm{O}$ (346.81): C, 55.41; $\mathrm{H}, 5.52 ; \mathrm{N}$, 24.23. Found C, 55.62; H, 5.68; N, 24.44. 
2-(2-(4-bromobenzylidene)hydrazinyl)-4-methoxy-6-(piperidin-1-yl)-1,3,5-triazine (4f). the product was obtained as a yellow solid in yield 85\%; mp 138-140 ${ }^{\circ} \mathrm{C}$; IR $\left(\mathrm{KBr}, \mathrm{cm}^{-1}\right): 3217(\mathrm{NH}), 1590(\mathrm{C}=\mathrm{N}), 1541$, $1462(\mathrm{C}=\mathrm{C}) ;{ }^{1} \mathrm{H}-\mathrm{NMR}\left(400 \mathrm{MHz}, \mathrm{DMSO}-d_{6}\right): \delta=1.47$ (brs, $\left.4 \mathrm{H}, 2 \mathrm{CH}_{2}\right), 1.58$ (brs, 2H, $\left.\mathrm{CH}_{2}\right), 3.69(\mathrm{brs}, 4 \mathrm{H}$, $\left.2 \mathrm{CH}_{2} \mathrm{~N}\right), 3.79\left(\mathrm{~s}, 3 \mathrm{H}, \mathrm{OCH}_{3}\right), 7.54-7.59(\mathrm{~m}, 4 \mathrm{H}, \mathrm{Ar}), 8.03(\mathrm{~s}, 1 \mathrm{H}, \mathrm{CH}), 11.16(\mathrm{~s}, 1 \mathrm{H}, \mathrm{NH}) \mathrm{ppm} ;{ }^{13} \mathrm{C}-\mathrm{NMR}$ $\left(100 \mathrm{MHz}, \mathrm{DMSO}-d_{6}\right): \delta=24.7,25.9,43.7,54.1,122.9,128.8,130.7,132.3,134.6,142.1,165.8,171.4 \mathrm{ppm}$. Anal. Calc. for $\mathrm{C}_{16} \mathrm{H}_{19} \mathrm{BrN}_{6} \mathrm{O}$ (391.27): C, 49.12; H, 4.89; N, 21.48. Found C, 49.33; H, 4.97; N, 21.67.

4,4'-(6-(2-(4-fluorobenzylidene)hydrazinyl)-1,3,5-triazine-2,4-diyl)di morpholine(4g). the product was obtained as a white solid in yield 74\%; mp 140-142 ${ }^{\circ} \mathrm{C}$; IR $\left(\mathrm{KBr}, \mathrm{cm}^{-1}\right): 3253(\mathrm{NH}), 1662(\mathrm{C}=\mathrm{N}), 1619$, $\left.1510(\mathrm{C}=\mathrm{C}) ;{ }^{1} \mathrm{H}-\mathrm{NMR}\left(400 \mathrm{MHz}, \mathrm{DMSO}_{-}\right)_{6}\right): \delta=3.54$ (brs, 4H, $\left.2 \mathrm{OCH}_{2}-\right), 3.65$ (brs, 4H, $\left.2 \mathrm{NCH}_{2}-\right)$, 4.42-4.48 (m, 2H, CH $-\mathrm{NH}), 7.16(\mathrm{t}, 1 \mathrm{H}, J=7.25 \mathrm{~Hz}, \mathrm{Ar}), 7.24-7.31(\mathrm{~m}, 4 \mathrm{H}, \mathrm{Ar}), 7.36(\mathrm{t}, 3 \mathrm{H}, J=7.5 \mathrm{~Hz}$, Ar), $7.59(\mathrm{~d}, 2 \mathrm{H}, J=7.5 \mathrm{~Hz}, \mathrm{Ar}), 8.06(\mathrm{~s}, 1 \mathrm{H}, \mathrm{CH}), 10.73(\mathrm{~s}, 1 \mathrm{H}, \mathrm{NH}) \mathrm{ppm},{ }^{13} \mathrm{C}-\mathrm{NMR}\left(100 \mathrm{MHz}, \mathrm{DMSO}-d_{6}\right)$ : $\delta=43.2,43.6,65.9,126.4,126.5,127.3,128.1,128.7,128.9,135.1,140.5,141.6,164.2,164.7,164.9$ ppm. Anal. Calc. for: $\mathrm{C}_{21} \mathrm{H}_{23} \mathrm{~N}_{7} \mathrm{O}$ (389.45): C, 64.76; H, 5.95; N, 25.18. Found C, 64.91; H, 6.03; N, 25.33.

N-benzyl-4-(2-(4-chlorobenzylidene)hydrazinyl)-6-morpholino-1,3,5-triazin-2-amine (4h). the product was obtained as a yellow solid in yield 77\%; mp 260-262 ${ }^{\circ} \mathrm{C}$; IR (KBr, cm-1): $3272(\mathrm{NH}), 1658(\mathrm{C}=\mathrm{N}), 1613$, $1513(\mathrm{C}=\mathrm{C}) ;{ }^{1} \mathrm{H}-\mathrm{NMR}\left(400 \mathrm{MHz}, \mathrm{DMSO}-d_{6}\right): \delta=3.58$ (brs, 4H, $\left.2 \mathrm{OCH}_{2}-\right), 3.71$ (brs, 4H, $\left.2 \mathrm{NCH}_{2}-\right)$, 4.47-4.51 (m, 2H, CH $-\mathrm{NH}), 7.26-7.33(\mathrm{~m}, 3 \mathrm{H}, \mathrm{Ar}), 7.44(\mathrm{~d}, 2 \mathrm{H}, J=9.0 \mathrm{~Hz}, \mathrm{Ar}), 7.54(\mathrm{~d}, 2 \mathrm{H}, J=8.5 \mathrm{~Hz}$, Ar), 7.86 (d, 2H, J = 8.5 Hz, Ar), 8.11 (s, 1H, CH), 10.81 (brs, 1H, NH) ppm; ${ }^{13}$ C-NMR $(100 \mathrm{MHz}$, DMSO- $\left.d_{6}\right): \delta 43.3,44.1,66.6,127.6,128.0,128.8,129.3,129.6,130.6,133.1,136.6,140.6,161.4,164.2$ ppm. Anal. Calc. for: $\mathrm{C}_{21} \mathrm{H}_{22} \mathrm{ClN}_{7} \mathrm{O}$ (423.90): C, 59.50; H, 5.23; N, 23.13. Found C, 59.67; H, 5.34; N, 23.31.

N-benzyl-4-(2-(4-bromobenzylidene)hydrazinyl)-6-morpholino-1,3,5-triazin-2-amine (4i). the product was obtained as a yellow solid in yield 75\%; mp 256-258 ${ }^{\circ} \mathrm{C}$; IR (KBr, cm-1): 3424(NH), 1657(C=N), 1613,1513(C=C) ${ }_{i}^{1} \mathrm{H}-\mathrm{NMR}\left(400 \mathrm{MHz}, \mathrm{DMSO}-d_{6}\right): \delta=3.57$ (brs, 4H, $\left.2 \mathrm{OCH}_{2^{-}}\right), 3.69$ (brs, 4H, $\left.2 \mathrm{NCH}_{2^{-}}\right)$, 4.48 (brs, 2H, CH $2-\mathrm{NH}), 7.18-7.32$ (m, 5H, Ar), 7.56-7.58 (m, 4H, Ar), 8.08 (s, 1H, CH), 10.81 (s, 1H, NH) ppm; ${ }^{13}$ C-NMR (100 MHz, DMSO- $\left.d_{6}\right): \delta 43.2,44.1,66.4,127.1,127.5,128.7,128.9,130.7,131.9,132.6$, 134.2, 137.3, 140.9, 161.3, 164.8 ppm. Anal. Calc. for: $\mathrm{C}_{21} \mathrm{H}_{22} \mathrm{BrN}_{7} \mathrm{O}$ (468.35): C, 53.85; H, 4.73; N, 20.93. Found C, 53.61; H, 4.62; N, 21.14 .

4-(4-(2-benzylidenehydrazinyl)-6-methoxy-1,3,5-triazin-2-yl)morpholine (4j). the product was obtained as a white solid in yield 74\%; mp 144-146 ${ }^{\circ} \mathrm{C}$; IR $\left(\mathrm{KBr}, \mathrm{cm}^{-1}\right)$ : 3353(NH), 1677(C=N), 1583,1537(C=C); ${ }^{1} \mathrm{H}-\mathrm{NMR}$ $\left(400 \mathrm{MHz}, \mathrm{DMSO}-d_{6}\right): \delta=3.60$ (brs, 4H, $\left.2 \mathrm{OCH}_{2}-\right), 3.70$ (brs, 4H, $\left.2 \mathrm{NCH}_{2}-\right), 3.80\left(\mathrm{~s}, 3 \mathrm{H}, \mathrm{OCH}_{3}\right), 7.32-7.39$ $(\mathrm{m}, 3 \mathrm{H}, \mathrm{Ar}), 7.62(\mathrm{~d}, 2 \mathrm{H}, \mathrm{J}=6.5 \mathrm{~Hz}, \mathrm{Ar}), 8.08(\mathrm{~s}, 1 \mathrm{H}, \mathrm{CH}), 11.17(\mathrm{~s}, 1 \mathrm{H}, \mathrm{NH}) \mathrm{ppm} ;{ }^{13} \mathrm{C}-\mathrm{NMR}(100 \mathrm{MHz}$, DMSO- $\left.d_{6}\right): \delta 43.4,53.7,65.9,126.6,128.7,129.3,134.7,143.2,165.3,165.7$ ppm. Anal. Calc. for: $\mathrm{C}_{15} \mathrm{H}_{18} \mathrm{~N}_{6} \mathrm{O}_{2}$ (314.34): C, 57.31; H, 5.77; N, 26.74. Found C, 57.55; H, 5.89; N, 26.93.

4-(4-(2-(4-chlorobenzylidene)hydrazinyl)-6-methoxy-1,3,5-triazin-2-yl)morpholine (4k). the product was obtained as a white solid in yield 77\%; mp 240-242 ${ }^{\circ} \mathrm{C}$; IR (KBr, cm-1): 3220(NH), 1588(C=N), 1542,1460(C=C); ${ }^{1} \mathrm{H}-\mathrm{NMR}\left(400 \mathrm{MHz}, \mathrm{DMSO}-d_{6}\right): \delta=3.60$ (brs, $\left.4 \mathrm{H}, 2 \mathrm{OCH}_{2}-\right), 3.69$ (brs, $\left.4 \mathrm{H}, 2 \mathrm{NCH}_{2}-\right)$, $3.80\left(\mathrm{~s}, 3 \mathrm{H}, \mathrm{OCH}_{3}\right), 7.44(\mathrm{dd}, 2 \mathrm{H}, J=6.5,2.5 \mathrm{~Hz}, \mathrm{Ar}), 7.63(\mathrm{dd}, 2 \mathrm{H}, J=6.5,2.5 \mathrm{~Hz}, \mathrm{Ar}), 8.06(\mathrm{~s}, 1 \mathrm{H}, \mathrm{CH})$, 11.24 (s, 1H, NH) ppm; ${ }^{13} \mathrm{C}-\mathrm{NMR}\left(100 \mathrm{MHz}, \mathrm{DMSO}-d_{6}\right): \delta 43.4,54.2,66.4,128.7,129.4,130.6,134.2$, 142.4, 161.6, 165.8 ppm. Anal. Calc. for: $\mathrm{C}_{15} \mathrm{H}_{17} \mathrm{ClN}_{6} \mathrm{O}_{2}$ (348.79): C, 51.65; $\mathrm{H}, 4.91 ; \mathrm{N}, 24.09$. Found C, $51.82 ; \mathrm{H}, 4.83 ; \mathrm{N}, 24.31$.

4-(4-(2-(4-bromobenzylidene)hydrazinyl)-6-methoxy-1,3,5-triazin-2-yl)morpholine (41). the product was obtained as a white solid in yield 76\%; mp 234-236 ${ }^{\circ} \mathrm{C}$; IR (KBr, cm-1): 3228(NH), $1584(\mathrm{C}=\mathrm{N})$, $1538,1462(\mathrm{C}=\mathrm{C}) ;{ }^{1} \mathrm{H}-\mathrm{NMR}\left(400 \mathrm{MHz}, \mathrm{DMSO}-d_{6}\right): \delta=3.64\left(\mathrm{~d}, 4 \mathrm{H}, J=4.4 \mathrm{~Hz}, 2 \mathrm{OCH}_{2}-\right), 3.73(\mathrm{brs}, 4 \mathrm{H}$, $\left.2 \mathrm{NCH}_{2-}\right), 3.83\left(\mathrm{~s}, 3 \mathrm{H}, \mathrm{OCH}_{3}\right), 7.59$ (s, 4H, Ar), 8.07 (s, 1H, CH), $11.26(\mathrm{~s}, 1 \mathrm{H}, \mathrm{NH}) \mathrm{ppm} ;{ }^{13} \mathrm{C}-\mathrm{NMR}(100$ $\left.\mathrm{MHz}, \mathrm{DMSO}-d_{6}\right): \delta 43.4,53.7,65.9,122.4,128.3,131.7,134.0,141.9,164.8,166.4$ ppm. Anal. Calc. for: $\mathrm{C}_{15} \mathrm{H}_{17} \mathrm{BrN}_{6} \mathrm{O}_{2}$ (393.24): C, 45.81; H, 4.36; N, 21.37. Found C, 45.99; H, 4.51; N, 21.59. 
4-(2-benzylidenehydrazinyl)-6-morpholino-N-phenyl-1,3,5-triazin-2-amine (4m). the product was obtained as a white solid in yield $84 \%$; $\mathrm{mp} 244-246{ }^{\circ} \mathrm{C}$; IR $\left(\mathrm{KBr}, \mathrm{cm}^{-1}\right)$ : 3259(NH), 1608(C=N), 1551,1503(C=C); ${ }^{1} \mathrm{H}-\mathrm{NMR}\left(400 \mathrm{MHz}, \mathrm{DMSO}-d_{6}\right): \delta=3.65\left(\mathrm{~d}, 4 \mathrm{H}, J=4.4 \mathrm{~Hz}, 2 \mathrm{OCH}_{2}-\right), 3.75$ (brs, $\left.4 \mathrm{H}, 2 \mathrm{NCH}_{2}-\right)$, $6.95(\mathrm{t}, 1 \mathrm{H}, J=7.6 \mathrm{~Hz}, \mathrm{Ar}), 7.27(\mathrm{t}, 2 \mathrm{H}, J=8.0 \mathrm{~Hz}, \mathrm{Ar}), 7.36-7.45(\mathrm{~m}, 3 \mathrm{H}, \mathrm{Ar}), 7.67(\mathrm{~d}, 2 \mathrm{H}, J=8.5 \mathrm{~Hz}, \mathrm{Ar})$, 7.83 (brs, 2H, Ar), 8.14 (s, 1H, CH), 9.30 (brs, 1H, NH), 10.92 (brs, 1H, NH) ppm; ${ }^{13} \mathrm{C}-\mathrm{NMR}(100 \mathrm{MHz}$, DMSO- $\left.d_{6}\right): \delta 43.2,66.0,119.7,121.6,126.5,128.4,128.7,129.1,135.1,140.3,142.2,164.2,164.8$ ppm. Anal. Calc. for: $\mathrm{C}_{20} \mathrm{H}_{21} \mathrm{~N}_{7} \mathrm{O}$ (375.43): C, 63.98; H, 5.64; N, 26.12. Found $\mathrm{C}, 64.08 ; \mathrm{H}, 5.77 ; \mathrm{N}, 26.36$.

4-(2-(4-chlorobenzylidene)hydrazinyl)-6-morpholino-N-phenyl-1,3,5-triazin-2-amine (4n). the product was obtained as a white solid in yield $84 \%$; mp 258-260 ${ }^{\circ} \mathrm{C}$; $\mathrm{IR}(\mathrm{KBr}, \mathrm{cm}-1)$ : 3253(NH), $1586(\mathrm{C}=\mathrm{N}), 1544$, $1510(\mathrm{C}=\mathrm{C}) ;{ }^{1} \mathrm{H}-\mathrm{NMR}\left(400 \mathrm{MHz}, \mathrm{DMSO}-d_{6}\right): \delta=3.65(\mathrm{~d}, 4 \mathrm{H}, J=4.4 \mathrm{~Hz}, 2 \mathrm{OCH} 2-), 3.75(\mathrm{brs}, 4 \mathrm{H}, 2$ $\left.\mathrm{NCH}_{2}-\right), 6.95(\mathrm{t}, 1 \mathrm{H}, J=7.6 \mathrm{~Hz}, \mathrm{Ar}), 7.28(\mathrm{t}, 2 \mathrm{H}, J=7.8 \mathrm{~Hz}, \mathrm{Ar}), 7.50(\mathrm{~d}, 2 \mathrm{H}, J=8.0 \mathrm{~Hz}, \mathrm{Ar}), 7.68(\mathrm{~d}, 2 \mathrm{H}$, $J=8.8 \mathrm{~Hz}, \mathrm{Ar}$ ), 7.82 (brs., 2H, Ar), 8.12 (s, 1H, CH), 9.33 (brs., 1H, NH), 10.99 (brs., $1 \mathrm{H}, \mathrm{NH}$ ) ppm;

${ }^{13} \mathrm{C}-\mathrm{NMR}\left(100 \mathrm{MHz}\right.$, DMSO- $\left.d_{6}\right): \delta 43.4,66.0,119.8,121.5,127.8,128.1,128.9,133.4,133.9,140.3,141.0$, 164.1, 164.2, 164.8 ppm. Anal. Calc. for: $\mathrm{C}_{20} \mathrm{H}_{20} \mathrm{ClN}_{7} \mathrm{O}$ (409.87): $\mathrm{C}, 58.61 ; \mathrm{H}, 4.92 ; \mathrm{N}, 23.92$. Found $\mathrm{C}$, 58.79; H, 5.04; N, 24.12.

4-(2-(4-bromobenzylidene)hydrazinyl)-6-morpholino-N-phenyl-1,3,5-triazin-2-amine (4o). the product was obtained as a white solid in yield 85\%; mp 259-261 ${ }^{\circ} \mathrm{C}$; IR $\left(\mathrm{KBr}, \mathrm{cm}^{-1}\right): 3249(\mathrm{NH}), 1586(\mathrm{C}=\mathrm{N}), 1547$, $1510(\mathrm{C}=\mathrm{C}) ;{ }^{1} \mathrm{H}-\mathrm{NMR}\left(400 \mathrm{MHz}, \mathrm{DMSO}-d_{6}\right): \delta=3.65(\mathrm{~d}, 4 \mathrm{H}, J=4.4 \mathrm{~Hz}, 2 \mathrm{OCH} 2-), 3.75$ (brs, $4 \mathrm{H}, 2$ $\left.\mathrm{NCH}_{2}-\right), 6.94(\mathrm{t}, 1 \mathrm{H}, J=7.4 \mathrm{~Hz}, \mathrm{Ar}), 7.27(\mathrm{t}, 2 \mathrm{H}, J=8.2 \mathrm{~Hz}, \mathrm{Ar}), 7.62(\mathrm{brs}, 4 \mathrm{H}, \mathrm{Ar}), 7.82(\mathrm{brs}, 2 \mathrm{H}, \mathrm{Ar}), 8.11$ (s, $1 \mathrm{H}, \mathrm{CH}), 9.34$ (brs, $1 \mathrm{H}, \mathrm{NH}), 10.99$ (brs., $1 \mathrm{H}, \mathrm{NH}) \mathrm{ppm} ;{ }^{13} \mathrm{C}-\mathrm{NMR}\left(100 \mathrm{MHz}, \mathrm{DMSO}-\mathrm{d}_{6}\right.$ ): $\delta=43.4$, 66.0, 119.8, 121.6, 122.1, 128.3, 131.7, 134.3, 140.3, 141.1, 164.2, 164.8 ppm. Anal. Calc. for $\mathrm{C}_{20} \mathrm{H}_{20} \mathrm{BrN}_{7} \mathrm{O}$ (454.32): C, 52.87; H, 4.44; N, 21.58. Found C, 53.03; H, 4.54; N, 21.79.

4-(2-benzylidenehydrazinyl)-6-methoxy-N-phenyl-1,3,5-triazin-2-amine (4p). the product was obtained as a white solid in yield $83 \%$; $\mathrm{mp} 148-150^{\circ} \mathrm{C}$; IR $\left(\mathrm{KBr}, \mathrm{cm}^{-1}\right)$ : 3254(NH), 1590(C=N), 1506, 1423(C=C); ${ }^{1} \mathrm{H}-\mathrm{NMR}\left(400 \mathrm{MHz}, \mathrm{DMSO}-d_{6}\right): \delta=3.68\left(\mathrm{~s}, 3 \mathrm{H}, \mathrm{OCH}_{3}\right), 6.81(\mathrm{~d}, 3 \mathrm{H}, J=9.5 \mathrm{~Hz}, \mathrm{Ar}), 7.30-7.40(\mathrm{~m}, 3 \mathrm{H}$, Ar), 7.62 (d, 2H, J = 7.5 Hz, Ar), 7.70 (brs, 2H, Ar), 8.11 (s, 1H, CH), 9.05 (brs., $1 \mathrm{H}, \mathrm{NH}), 10.73$ (brs, $1 \mathrm{H}$, $\mathrm{NH}) \mathrm{ppm} ;{ }^{13} \mathrm{C}-\mathrm{NMR}\left(100 \mathrm{MHz}\right.$, DMSO-d $\left.d_{6}\right): \delta=55.1,113.5,120.9,126.3,128.6,132.9,133.7,135.2,141.7$, 154.1, 164.0, 164.2ppm. Anal. Calc. for $\mathrm{C}_{17} \mathrm{H}_{16} \mathrm{~N}_{6} \mathrm{O}$ (320.35): $\mathrm{C}, 63.74 ; \mathrm{H}, 5.03 ; \mathrm{N}, 26.23$. Found $\mathrm{C}, 63.93$; $\mathrm{H}, 5.13 ; \mathrm{N}, 26.47$.

4-(2-(4-chlorobenzylidene)hydrazinyl)-6-methoxy-N-phenyl-1,3,5-triazin-2-amine (4q). the product was obtained as a white solid in yield $81 \%$; $\mathrm{mp} 178-180^{\circ} \mathrm{C}$; IR $(\mathrm{KBr}, \mathrm{cm}-1)$ : $3346(\mathrm{NH}), 1649(\mathrm{C}=\mathrm{N})$, 1515,1417(C=C); ${ }^{1} \mathrm{H}-\mathrm{NMR}\left(400 \mathrm{MHz}, \mathrm{DMSO}-d_{6}\right): \delta=3.68\left(\mathrm{~s}, 3 \mathrm{H}, \mathrm{OCH}_{3}\right), 6.81(\mathrm{~d}, 3 \mathrm{H}, J=9.0 \mathrm{~Hz}, \mathrm{Ar})$, $7.46(\mathrm{~d}, 2 \mathrm{H}, J=8.5 \mathrm{~Hz}, \mathrm{Ar}), 7.62-7.69(\mathrm{~m}, 4 \mathrm{H}, \mathrm{Ar}), 8.09$ (s, 1H, CH), 9.07 (brs, $1 \mathrm{H}, \mathrm{NH}), 10.80$ (brs., $1 \mathrm{H}$, $\mathrm{NH}) \mathrm{ppm} ;{ }^{13} \mathrm{C}-\mathrm{NMR}\left(100 \mathrm{MHz}, \mathrm{DMSO}-d_{6}\right): \delta 55.1,113.5,120.9,127.8,128.8,133.2,133.7,134.2,140.3$, 154.1, 164.0, 164.2 ppm. Anal. Calc. for: $\mathrm{C}_{17} \mathrm{H}_{15} \mathrm{ClN}_{6} \mathrm{O}$ (354.79): $\mathrm{C}, 57.55 ; \mathrm{H}, 4.26 ; \mathrm{N}, 23.69$. Found $\mathrm{C}$, $57.79 ; \mathrm{H}, 4.37 ; \mathrm{N}, 23.91$.

3.1.18. 4-(2-(4-bromobenzylidene)hydrazinyl)-6-methoxy-N-phenyl-1,3,5-triazin-2-amine (4r). the product was obtained as a white solid in yield $77 \%$; $\mathrm{mp} 173-175^{\circ} \mathrm{C}$; IR $(\mathrm{KBr}, \mathrm{cm}-1)$ : $3333(\mathrm{NH}), 1655(\mathrm{C}=\mathrm{N})$, $1556,1515(\mathrm{C}=\mathrm{C}){ }^{1}{ }^{1} \mathrm{H}-\mathrm{NMR}\left(400 \mathrm{MHz}, \mathrm{DMSO}-d_{6}\right): \delta=3.71\left(\mathrm{~s}, 3 \mathrm{H}, \mathrm{OCH}_{3}\right), 6.84(\mathrm{~d}, 3 \mathrm{H}, J=6.5 \mathrm{~Hz}, \mathrm{Ar})$, 6.85-7.72 (m, 6H, Ar), 8.11 (s, 1H, CH), 9.10 (brs., 1H, NH), 10.83 (brs, 1H, NH) ppm; ${ }^{13} \mathrm{C}-\mathrm{NMR}$ $\left(100 \mathrm{MHz}\right.$, DMSO- $\left.d_{6}\right): \delta 55.1,113.5,120.9,121.9,128.1,131.7,133.7,134.5,140.4,154.1,164.0,164.2 \mathrm{ppm}$. Anal. Calc. for: $\mathrm{C}_{17} \mathrm{H}_{15} \mathrm{BrN}_{6} \mathrm{O}$ (399.24): $\mathrm{C}, 51.14 ; \mathrm{H}, 3.79 ; \mathrm{N}, 21.05$. Found $\mathrm{C}, 51.31 ; \mathrm{H}, 3.92 ; \mathrm{N}, 21.28$.

\subsection{Biology}

\subsubsection{In Vitro Anti-Proliferative Assay}

The synthesized compounds 4a-r were evaluated for anti-proliferative using the MTT viability assay of MCF-7 and HCT-116 cell lines and to calculate the relative $\mathrm{IC}_{50}$ values for each compound as illustrated in the (Supporting information, Method S1). 


\subsubsection{Annexin V/PI Apoptotic Assay:}

Apoptotic cell death was detected by flow cytometry using Annexin V and propidium iodide (PI). MCF-7 cells were seeded in 6 well plated at density of $1 \times 10^{5}$ cells $/ \mathrm{mL}$ and treated with vehicle $(0.1 \%(\mathrm{v} / \mathrm{v}) \mathrm{DMSO})$ and compound $\mathbf{4 b}(6 \mu \mathrm{M})$ for $24 \mathrm{~h}$. Cells were then harvested and prepared for flow cytometric analysis as illustrated in the (Supporting information, Method S2).

\subsubsection{Molecular Docking Study}

The 3ERT X-ray structure of hER $\alpha$ co-crystallized with 4-hydroxytamoxifen (4-OHT) [44] was downloaded from the protein data bank (PDB) website. The crystal structure was prepared using QuickPrep (minimized to a gradient of $0.001 \mathrm{kcal} / \mathrm{mol} / \AA$ ), Protonate 3D, Residue pKa and Partial Charges protocols in MOE 2019 [45] with the MMFF94x force field. All compounds were drawn in ChemBioDraw Ultra 13.0.2.3021 (PerkinElmer), converted to sd files within Pipeline Pilot [46] and read into a MOE mdb file. For each compound, MMFF94x partial charges were calculated and each was minimized to a gradient of $0.001 \mathrm{kcal} / \mathrm{mol} / \AA ̊$. Default parameters were used for docking except that 300 poses were sampled for each compound and the top 50 docked poses were retained for subsequent analysis.

\section{Conclusions}

In summary, the synthesized compounds in this study showed varied activity against two cell lines MCF-7 and HCT-116. Generally, the nature of the substituents on the triazine ring significantly influenced the biological activity. Compounds with piperidine and benzylamine moieties on the triazine core 4a-c showed the most potent anti-proliferative activity with $\mathrm{IC}_{50}$ values in range of 3.29-11.35 $\mu \mathrm{M}$ and $3.64-12.45 \mu \mathrm{M}$ for MCF-7 and HCT-116 cells, respectively compared with tamoxifen as a reference compound ( $\mathrm{IC}_{50}$ values of 5.12 and $26.41 \mu \mathrm{M}$ in MCF-7 and HCT-116 cells, respectively) and their analogs with substituted morpholine and benzylamine $4 \mathbf{g}-\mathbf{i}$ ( $\mathrm{IC}_{50}$ values in range of $16.44-24.46 \mu \mathrm{M}$ and $8.19-14.01 \mu \mathrm{M}$ in MCF-7 and HCT-116 cells, respectively). Furthermore, compounds $4 \mathbf{m}-\mathbf{o}$ (morpholine and phenylamine) exhibited better activity compared to their analogous $4 \mathbf{p}-\mathbf{r}$ (methoxy and phenylamine). In addition, the substituent on the benzylidene ring showed great impact on the anti-proliferative activity, where the chloro derivatives showed better anti-cancer activities compared to other unsubstituted and bromo substituent analogs. The obtained results are consistent with the previously reported results, where the presence of piperidine on the s-triazine ring and the presence of an electronegative atom on the benzylidene increased the compounds activity against the cancer cells [32-35].

The results demonstrate that derivative $4 \mathrm{~b}$ can induce apoptosis in MCF-7 cells. Indeed, the results obtained from the molecular docking agreed with the anti-proliferative activity assay, where the combination of the piperidino and benzylamino on the s-triazine core is the optimal configuration.

Plans for future optimization of the triazine compound series ER binding affinity include introducing hydrogen bonding acceptor moieties ortho and/or meta on the halogenated benzylidene ring and hydrogen bond donating moieties para on the benzyl ring so as to more fully mimic the 4-OHT binding interactions.

Supplementary Materials: The following are available online: http://www.mdpi.com/1420-3049/25/18/4065/s1, Figures S1-S18: represented the spectral data $\left({ }^{1} \mathrm{H}\right.$ and ${ }^{13} \mathrm{C}-\mathrm{NMR}$ spectra) for all prepared compounds.

Author Contributions: The work designed and supervised by A.E.-F.; H.H.A.R., K.A.D. and A.M.M. carried out synthesis and characterization of the reported compounds; A.M.M. and D.F. carried the biological activity and computational studies respectively. All authors discussed the results. The first drafts of the manuscript was prepared by H.H.A. and A.M. All authors have read and agreed to the published version of the manuscript.

Funding: Deanship of Scientific Research at King Saud University, research group no. (RG-1441-365, Saudi Arabia).

Acknowledgments: The authors extend their appreciation to the Deanship of Scientific Research at King Saud University for funding this work through research group no. (RG-1441-365, Saudi Arabia). The Trinity Biomedical 
Sciences Institute is supported by a capital infrastructure investment from Cycle 5 of the Irish Higher Education Authority's Programme for Research in Third Level Institutions (PRTLI). D.F. thanks the software vendors for their continuing support of academic research efforts, in particular the contributions of Biovia, the Chemical Computing Group, and OpenEye Scientific. The support and provisions of Dell Ireland, the Trinity Centre for High Performance Computing (TCHPC), and the Irish Centre for High-End Computing (ICHEC) are also gratefully acknowledged.

Conflicts of Interest: The authors declare no conflict of interest

\section{References}

1. Zhou, C.; Min, J.; Liu, Z.; Young, A.; Deshazer, H.; Gao, T.; Chang, Y.T.; Kallenbach, N.R. Synthesis and biological evaluation of novel 1,3,5-triazinederivatives as antimicrobial agents. Bioorg. Med. Chem. Lett. 2008, 18, 1308-1311. [CrossRef] [PubMed]

2. Solankee, A.; Kapadia, K.; Ciric, A.; Sokovic, M.; Doytchinova, I.; Geronikaki, A. Synthesis of some new s-triazine based chalcones and their derivatives as potent antimicrobial agents. Eur. J. Med. Chem. 2010, 45, 510-518. [CrossRef] [PubMed]

3. Patel, R.V.; Kumari, P.; Chikhalia, K.H. Design, synthesis and antimicrobial screening of s-triazinyl piperazine and piperidine derivatives. Int. J. Adv. Pharm. Sci. 2010, 1, 395-403.

4. Kumar, G.V.P.; Srinivasa, R.D.; Pooja, B.; Harika, G.; Kumar, Y.A.; Sadasiva, R.G. An extensive review on 1,2,3 and 1,2,4-triazines scaffold-valuable lead molecules with potent and diverse pharmacological activities. Der Chem. Sin. 2016, 7, 101-130.

5. Ma, X.; Tan, S.-T.; Khoo, C.-L.; Sim, H.-M.; Chan, L.-W.; Chui, W.K. Synthesis and antimicrobial activity of $N^{1}$-benzyl or $N^{1}$-benzyloxy-1, 6-dihydro-1,3, 5 triazine-2, 4-diamines. Bioorg. Med. Chem. Lett. 2011, 21, 5428-5431. [CrossRef]

6. Sharma, A.; Singh, S.; Utreja, D. Recent Advances in Synthesis and antifungal activity of 1,3,5-triazines. Curr. Org. Synth. 2016, 13, 484-503. [CrossRef]

7. Manohar, S.; Khan, S.I.; Rawat, D.S. 4-Aminoquinoline-triazine-based hybrids with improved in vitro antimalarial activity against CQ-sensitive and CQ-resistant strains of plasmodium falciparum. Chem. Biol. Drug Des. 2013, 81, 625-630. [CrossRef]

8. Garaj, V.; Puccetti, L.; Fasolis, G.; Winum, J.Y.; Montero, J.L.; Scozzafava, A.; Vullo, D.; Innocenti, A.; Supuran, C.T. Carbonic anhydrase inhibitors: Synthesis and inhibition of cytosolic/tumor-associated carbonic anhydrase isozymes I, II, and IX with sulfonamides incorporating 1,2,4-triazine moieties. Bioorg. Med. Chem. Lett. 2004, 14, 5427-5433. [CrossRef]

9. Garaj, V.; Puccetti, L.; Fasolis, G.; Winum, J.Y.; Montero, J.L.; Scozzafava, A.; Vullo, D.; Innocenti, A.; Supuran, C.T. Carbonic anhydrase inhibitors: Novel sulfonamides incorporating 1,3,5-triazine moieties as inhibitors of the cytosolic and tumour-associated carbonic anhydrase isozymes I, II, and IX. Bioorg. Med. Chem. Lett. 2005, 15, 3102-3108. [CrossRef]

10. Ceruso, M.; Vullo, D.; Scozzafava, A.; Supuran, C.T. Inhibition of human carbonic anhydrase isoforms I-XIV with sulfonamides incorporating fluorine and 1,3,5-triazine moieties. Bioorg. Med. Chem. 2013, 21, 6929-6936. [CrossRef]

11. Carta, F.; Garaj, V.; Maresca, A.; Wagner, J.; Avvaru, B.S.; Robbins, A.H.; Scozzafava, A.; McKenna, R.; Supuran, C.T. Sulfonamides incorporating 1,3,5-triazine moieties selectively and potently inhibit carbonic anhydrase transmembrane isoforms IX, XII, and XIV over cytosolic isoforms I and II: Solution and X-ray crystallographic studies. Bioorg. Med. Chem. 2011, 19, 3105-3119. [CrossRef] [PubMed]

12. Lolaka, N.; Akocaka, S.; Buab, S.; Supuranb, C.T. Design, synthesis and biological evaluation of novel ureido benzenesulfonamides incorporating 1,3,5-triazine moieties as potent carbonic anhydrase IX inhibitors. Bioorg. Chem. 2019, 82, 117-122. [CrossRef] [PubMed]

13. Zheng, M.; Xu, C.; Ma, J.; Sun, Y.; Du, F.; Liu, H.; Lin, L.; Li, C.; Ding, J.; Chen, K.; et al. Synthesis and antitumor evaluation of a novel series of triaminotriazine derivatives. Bioorg. Med. Chem. 2007, 15, 1815-1827. [CrossRef] [PubMed]

14. Patel, R.V.; Keum, Y.S.; Park, S.W. Medicinal chemistry discoveries among 1,3,5- triazines: Recent advances (2000-2013) as antimicrobial, anti-TB, anti-HIV and antimalarials. Mini Rev. Med. Chem. 2014, 14, 768-789. [CrossRef] [PubMed] 
15. Liu, B.; Sun, T.; Zhou, Z.; Du, L. A systematic review on antitumor agents with 1,3,5-triazines. Med. Chem. 2015, 5, 131-148. [CrossRef]

16. Cascioferro, S.; Parrino, B.; Spano, V.; Carbone, A.; Montalbano, A.; Barraja, P.; Diana, P.; Cirrincione, G. 1,3,5-Triazines: A promising scaffold, for anticancer drugs development. Eur. J. Med. Chem. 2017, 142, 523-549. [CrossRef]

17. Srivastava, G.K.; Alonso-Alonso, M.L.; Fernandez-Bueno, I.; Garcia-Gutierrez, M.T.; Rull, F.; Medina, J.; Coco, R.M.; Pastor, J.C. Comparison between direct contact and extract exposure methods for PFO cytotoxicity evaluation. Sci. Rep. 2018, 8, 1425. [CrossRef]

18. Desmukh, A.P.; Soni, P.K.; Kankoriya, A.; Halve, A.K.; Dixit, R. 4-Aminoantipyrine: A significant tool for the synthesis of biologically active Schiff bases and metal complexes. Int. J. Pharm. Sci. Rev. Res. 2015, 34, 162-170.

19. Goel, P.; Kumar, D.; Chandra, S. Schiff's Base Ligands and their transition metal complexes as Antimicrobial agents. J. Chem. Biol. Phy. Sci. 2014, 2014, 1946-1964.

20. Ebrahimipour, S.Y.; Khosravan, M.; White, J.; Fekri, S. Preparation, crystal structure, spectroscopic studies, DFT calculations, antibacterial activities and molecular docking of a tridentate Schiff base ligand and its cis- $\mathrm{MoO}_{2}$ complex. Appl. Organomet. Chem. 2018, 32, e4233. [CrossRef]

21. Kajal, A.; Bala, S.; Kamboj, S.; Sharma, N.; Saini, V. Schiff bases: A versatile pharmacophore. J. Catal. 2013, 2013, 14. [CrossRef]

22. Uddin, N.; Rashid, F.; Ali, S.; Tirmizi, S.A.; Ahmad, I.; Zaib, S.; Zubir, M.; Diaconescu, P.L.; Tahir, M.N.; Iqbal, J.; et al. Synthesis, characterization, and anticancer activity of Schiff bases. J. Biomol. Str. Dynam. 2020, 38, 3246-3259. [CrossRef] [PubMed]

23. Hassanpour, S.H.; Dehghani, M. Review of cancer from perspective of molecular. J. Cancer Res. Pract. 2017, 4, 127-129. [CrossRef]

24. Abd-Elzaher, M.M.; Labib, A.A.; Mousa, H.A.; Moustafa, S.A.; Ali, M.M.; El-Rashedy, A.A. Synthesis, anticancer activity and molecular docking study of Schiff base complexes containing thiazole moiety. Beni Suef Univ. J. Basic. Appl. Sci. 2016, 5, 85-96. [CrossRef]

25. Menear, K.A.; Gomez, S.; Malagu, K.; Bailey, C.; Blackburn, K.; Cockcroft, X.L.; Sebastian, L. Identification and optimisation of novel and selective small molecular weight kinase inhibitors of mTOR. Bioorg Med. Chem. Lett. 2009, 19, 5898-5901. [CrossRef]

26. Bai, F.; Liu, H.; Tong, L.; Zhou, W.; Liu, L.; Zhao, Z.; Liu, X.; Jiang, H.; Wang, X.; Xie, H. Discovery of novel selective inhibitors for EGFR-T790M/L858R. Bioorg. Med. Chem. Lett. 2012, 22, 1365-1370. [CrossRef]

27. Herke Herke, B.R.; Consler, T.G.; Go, N.; Hale, R.L.; Hohman, D.R.; Jones, S.A.; Lu, A.T.; Moore, L.B.; Moore, J.T.; Orband-Miller, L.A.; et al. A new series of estrogen receptor modulators that display selectivity for estrogen receptor. $\beta$ J. Med. Chem. 2002, 45, 5492-5505.

28. Hale, R.L.; Henke, B.R.; Lambert, M.H.; Lu, A.T.; Spearing, P.K.; Turnbull, P.S. Piperazinyltriazine as Estrogen Modulators. U.S. Patent 6,943,162 B2, 13 September 2005.

29. Lu, X.; Huang, A.; Xiao, M.; Sun, L.; Mao, J.; Luo, G.; Xiang, H. A new class of 1,3,5-triazine-based selective estrogen receptor degraders (SERDs): Lead optimization, molecular docking and dynamic simulation. Bioorg. Chem. 2020, 97, 103666. [CrossRef]

30. El-Faham, A.; Soliman, S.M.; Ghabbour, H.A.; Elnakady, Y.A.; Mohaya, T.A.; Siddiqui, M.R.; Albericio, F. Ultrasonic promoted synthesis of novel s-triazine-Schiff base derivatives; molecular structure, spectroscopic studies and their preliminary anti-proliferative activities. J. Mol. Str. 2016, 1125, 121-135. [CrossRef]

31. Barakat, A.; El-Senduny, F.F.; Almarhoon, Z.; Al-Rasheed, H.H.; Badria, F.A.; Al-Majid, A.M.; El-Faham, A. Synthesis, X-ray crystal structures, and preliminary antiproliferative activities of new s-triazine-hydroxybenzylidene hydrazone derivatives. J. Chem. 2019, 2019, 10. [CrossRef]

32. Al Rasheed, H.H.; Malebari, A.M.; Dahlous Kh., A.; El-Faham, A. Synthesis and characterization of new series of 1,3-5-triazine hydrazone derivatives with promising anti-proliferative activity. Molecules 2020, 25, 2708. [CrossRef] [PubMed]

33. Sharma, A.; Ghabbour, H.; Khan, S.T.; Beatriz, G.; Albericio, F.; El-Faham, A. Novel pyrazolyl-s-triazine derivatives, molecular structure and antimicrobial activity. J. Mol. Str. 2017, 1145, 244-253. [CrossRef]

34. El-Faham, A.A.; Elnakady, Y. Synthesis, characterization of novel morpholino-1, 3, 5-triazinyl amino acid Ester derivatives and their anti-proliferation activities. Lett. Org. Chem. 2015, 12, 753-758. [CrossRef]

35. Hassan, F.; Mohammed, G.; El-Hiti, G.A.; Alshanon, A.; Yousif, E. Cytotoxic effects of tamoxifen in breast cancer cells. J. Unexplored Med. Data 2018, 3, 1-9. [CrossRef] 
36. Al Rasheed, H.H.; Dahlous Kh., A.; Sharma, A.; Sholkamy, E.; El-Faham, A.; De La Torre, B.G.; Albericio, F. Barbiturate- and Thiobarbituarte-based s-triazine hydrazone derivatives with promising antiproliferative activities. ACS Omega 2020, 5, 15805-15811. [CrossRef]

37. Alaghaz, A.; Bayoumi, H.A. Synthesis, Spectral Properties and Potentiometric Studies on Some Metal Schiff Base Complexes Derived from 4-chlorophenyl-2-aminothiazole. Int. J. Electrochem. Sci. 2013, 8, 11860-11876.

38. Mojena, M.; Povo-Retana, A.; González-Ramos, S.; Fernández-García, V.; Regadera, J.; Zazpe, A.; Artaiz, I.; Martín-Sanz, P.; Ledo, F.; Boscá, L. Benzylamine and Thenylamine derived drugs induce apoptosis and reduce proliferation, migration and metastasis formation in melanoma cells. Front. Oncol. 2018, 8, 328. [CrossRef]

39. Carr, M.; Knox, A.J.; Lloyd, D.G.; Zisterer, D.M.; Meegan, M.J. Development of the $\beta$-lactam type molecular scaffold for selective estrogen receptor $\alpha$ modulator action: Synthesis and cytotoxic effects in MCF-7 breast cancer cells. J. Enzy. Inhib. Med. Chem. 2016, 31, 130-117. [CrossRef]

40. Ma, D.; Tremblay, P.; Mahngar, K.; Akbari-Asl, P.; Collins, J.; Hudlicky, T.; McNulty, J.; Pandey, S. A novel synthetic C-1 analogue of 7-deoxypancratistatin induces apoptosis in p53 positive and negative human colorectal cancer cells by targeting the mitochondria: Enhancement of activity by tamoxifen. Investig. New Drugs 2012, 30, 1012-1027. [CrossRef]

41. Tsai, M.J.; O'Malley, B.W. Molecular mechanisms of action of steroid/thyroid receptor superfamily members. Annu. Rev. Biochem. 1994, 63, 451-486. [CrossRef]

42. Ogawa, S.; Inoue, S.; Watanabe, T.; Hiroi, H.; Orimo, A.; Hosoi, T.; Ouchi, Y.; Muramatsu, M. The complete primary structure of human estrogen receptor beta (hER beta) and its heterodimerization with ER alpha in vivo and in vitro. Biochem. Biophys. Res. Commun. 1998, 243, 122-126. [CrossRef] [PubMed]

43. Filardo, E.J.; Quinn, J.A.; Bland, K.I.; Frackelton, A.R., Jr. Estrogen-induced activation of Erk-1 and Erk-2 requires the $\mathrm{G}$ protein-coupled receptor homolog, GPR30, and occurs via trans-activation of the epidermal growth factor receptor through release of HB-EGF. Mol. Endocrinol. 2000, 14, 1649-1660. [CrossRef] [PubMed]

44. Shiau, A.K.; Barstad, D.; Loria, P.M.; Cheng, L.; Kushner, P.J.; Agard, D.A.; Greene, G.L. The structural basis of estrogen receptor/coactivator recognition and the antagonism of this interaction by tamoxifen. Cell 1998, 95, 927-937. [CrossRef]

45. Chemical Computing Group. Molecular Operating Environment (MOE); ULC: Montreal, QC, Canada, 2020.

46. BIOVIA, Dassault Systèmes. Available online: http://accelrys.com/products/collaborative-science/bioviapipeline-pilot/ (accessed on 20 July 2020).

Sample Availability: Samples of the compounds are available from the authors.

(C) 2020 by the authors. Licensee MDPI, Basel, Switzerland. This article is an open access article distributed under the terms and conditions of the Creative Commons Attribution (CC BY) license (http://creativecommons.org/licenses/by/4.0/). 